\title{
Response to Letter to the Editor concerning Schmedding et al.: Decentralised surgery of abdominal wall defects in Germany (Pediatr Surg Int (2020) 36: 569-578)
}

\author{
Andrea Schmedding ${ }^{1}$
}

Accepted: 9 July 2020 / Published online: 22 July 2020

(c) The Author(s) 2020

\section{Dear Sir,}

We thank Dr. Schmiedecke and co-workers for commenting on our paper.

Our study utilized insurance data of patients with abdominal wall defects and identified mortality beside the length of hospital stay as one of the main outcome measures. Mortality is easy to assess in insurance data and is, therefore, an unbiased outcome parameter in this kind of studies. Somatic and psychosocial follow-up is impossible to evaluate using the provided insurance data, since they only cover 12 months after discharge from the first in-hospital stay.

We are appreciative of your comment on the missing table or graph on the case volume-mortality relation. Unfortunately, our study included specific insurance data, with no data of case numbers per treating institution due to data protection policy.

Our previous published study revealed that abdominal wall defects were treated in 86 paediatric surgical units with an average case load of less than five cases per institution [1]. Further, we have utilized the "Quality Reports of the Hospitals" (Gemeinsamer Bundesausschuss-GBA). The analysis of the Quality Reports revealed a maximum average case load of 12 procedures in only one institution for the period 2012-2015. No institution performed more than seven procedures for closure of abdominal wall defects in each of the specified years [2]. With these data, no high-volume centre

This reply refers to the comment available online at https://doi. org/10.1007/s00383-020-04717-w.

Andrea Schmedding

andrea.schmedding@kgu.de

1 Department of Pediatric Surgery and Pediatric Urology,

University Hospital, Goethe University Frankfurt,

Theodor-Stern-Kai 7, 60590 Frankfurt, Germany with an average of more than 15 cases per year could be identified for Germany.

Youssef et al. reported on higher mortality rates in complex gastroschisis in the US [3]. Our data confirmed a higher mortality of complex gastroschisis which corresponds with many other studies. We do agree with the statement that the current situation in Germany compares with that of the US.

Hong et al. and Dubrovsky et al. published that higher centre volumes were not associated with improved outcome $[4,5]$. This again is consistent with our findings. Sømme et al. investigated esophageal atresia, $\mathrm{CDH}$ and gastroschisis and did not find an association between volume and outcome [6].

The statement that paediatric surgeons oppose centralization in general is invalid, since it is not supported by available data. We completely agree to centralize complex paediatric surgical care. Furthermore, we call for a national registry for congenital anomalies as a basis for follow-up evaluation and quality management [7].

Sincerely

Andrea Schmedding.

Acknowledgments Open Access funding provided by Projekt DEAL.

Open Access This article is licensed under a Creative Commons Attribution 4.0 International License, which permits use, sharing, adaptation, distribution and reproduction in any medium or format, as long as you give appropriate credit to the original author(s) and the source, provide a link to the Creative Commons licence, and indicate if changes were made. The images or other third party material in this article are included in the article's Creative Commons licence, unless indicated otherwise in a credit line to the material. If material is not included in the article's Creative Commons licence and your intended use is not permitted by statutory regulation or exceeds the permitted use, you will need to obtain permission directly from the copyright holder. To view a copy of this licence, visit http://creativecommons.org/licenses/by/4.0/. 


\section{References}

1. Schmedding A, Rolle U (2017) Decentralized rather than centralized pediatric surgery care in Germany. Eur J Pediatr Surg 27:399-406

2. Gemeinsamer Bundesausschuss. Qualitätsberichte der Krankenhäuser gemäß $§ 137$ Abs. 3 Satz 1 Nr. 4 SGB V: Berichtsjahr 2010-2018. https://www.g-ba.de/qualitaetsbericht

3. Youssef F, Cheong LH, Emil S, Canadian Pediatric Surgery Network (CAPSNet) (2016) Gastroschisis outcomes in North America: a comparison of Canada and the United States. J Pediatr Surg 51:891-895. https://doi.org/10.1016/j.jpedsurg.2016.02.046

4. Hong CR, Fullerton BS, Han SM, Morrow KA, Edwards EM, Soll RF, Jaksic T, Horbar JD, Modi BP (2019) Impact of disease-specific volume and hospital transfer on outcomes in gastroschisis. J Pediatr Surg 54:65-69. https://doi.org/10.1016/j.jpeds urg.2018.10.034
5. Dubrovsky G, Sacks GD, Friedlander S, Lee S (2017) Understanding the relationship between hospital volume and patient outcomes for infants with gastroschisis. J Pediatr Surg 52:1977-1980. https ://doi.org/10.1016/j.jpedsurg.2017.08.065

6. Sømme S, Shahi N, McLeod L, Torok M, McManus B, Ziegler MM (2019) Pediatr Surg Int 35(11):1293-1300. https://doi. org/10.1007/s00383-019-04525-x (Epub 2019 Aug 1. PMID: 31372730)

7. Schmedding A, Rolle U (2020) Qualitätsmessung bei seltenen Erkrankungen-KinderRegister für angeborene Fehlbildungen. Passion Chirurgie 10(05):Artikel 03_01

Publisher's Note Springer Nature remains neutral with regard to jurisdictional claims in published maps and institutional affiliations. 